OPEN ACCESS

Edited by:

Robin Mahon,

The University of the West Indies,

Cave Hill, Barbados

Reviewed by:

Nong Hong,

Institute for China-America Studies

(ICAS), United States

Timo M. Koivurova,

University of Lapland, Finland

*Correspondence:

Natalie Degger

natalie@iwlearn.org

Specialty section:

This article was submitted to

Marine Affairs and Policy,

a section of the journal

Frontiers in Marine Science

Received: 23 December 2020

Accepted: 18 March 2021

Published: 03 May 2021

Citation:

Degger N, Hudson A, Mamaev V

Hamid M and Trumbic I (2021)

Navigating the Complexity of Regional

Ocean Governance Through

the Large Marine Ecosystems

Approach. Front. Mar. Sci. 8:645668.

doi: 10.3389/fmars.2021.645668

\section{Navigating the Complexity of Regional Ocean Governance Through the Large Marine Ecosystems Approach}

\author{
Natalie Degger ${ }^{1 *}$, Andrew Hudson ${ }^{2}$, Vladimir Mamaev ${ }^{3}$, Mish Hamid ${ }^{1}$ and Ivica Trumbic ${ }^{1}$ \\ ${ }^{1}$ GEF International Waters Learning Exchange and Resource Network, Marine Policy and Regional Coordination Section, \\ Intergovernmental Oceanographic Commission of UNESCO, Paris, France, ${ }^{2}$ Water and Ocean Governance Programme, \\ United Nations Development Programme, New York, NY, United States, ${ }^{3}$ Water and Ocean Governance Programme, United \\ Nations Development Programme, Istanbul, Turkey
}

Governance is a multifaceted and complex process, involving a wide range of stakeholders from numerous institutions and individuals with different interests, agendas and sets of skills. A number of barriers exist for states to work together on securing their shared coastal and marine ecosystems, with discussions often becoming clouded when disputes arise over Exclusive Economic Zones, borders, oil and gas resources, continental shelves, maritime transport, and fisheries. Over the last twenty-six years, the Global Environment Facility's (GEF) International Waters focal area has utilized the Large Marine Ecosystem (LME) approach to navigate the complex problems related to transboundary issues affecting the world's marine ecosystems, of which forty-one out of sixty-six are shared (62\%) by one or more countries. To overcome the disputes and assumptions about the intentions of neighboring states, the GEF developed the Transboundary Diagnostic Analysis-Strategic Action Programme (TDASAP) assessment and strategic planning processes to help countries learn how to work together and build trust. This formal and inclusive process analyses all pertinent factual and scientific information to set priorities for action. This practical method for integrating science into management has provided an effective approach to inform and advance sustainable LME management and governance regimes; however, there is not a one size fits all approach. This review presents six examples from the GEF International Waters portfolio that demonstrate how the LME Approach and TDA-SAP process have helped countries find the best way to mainstream ecosystem-based management approaches into existing contexts and politics. While these examples span a wide range of different settings (geographic, political, socio-economic, temporal), they have all applied the LME Approach and TDA-SAP process to tackle complex regional ocean governance issues. Each example provides a historical perspective, the key results achieved, and their unique lessons learned/best practices. Furthermore, the review identifies some of the overall shortcomings of the process and the common lessons learned, 
underscoring the complex and daunting challenge of achieving effective governance for multi-country LMEs. The experience provided by these examples shows that practical ecosystem-based management of the ocean and its coasts not only requires flexibility and adaptability, but also time, associated long-term vision and commitment.

Keywords: Large Marine Ecosystems Approach, Transboundary Diagnostic Analysis, Strategic Action Programme, International Waters, governance

\section{INTRODUCTION}

The Large Marine Ecosystem (LME) Approach for the assessment and management of coastal and ocean ecosystem services has gained momentum since the mid-1980s (Sherman, 2005). It combines the legal principles of the United Nations Convention on the Law of the Sea (UNCLOS) with a multi-sectoral and multidisciplinary strategy for assessing and managing the changing state of the world's sixty-six LMEs (Sherman, 2019). These highly productive areas of the ocean share six main priority threats (United Nations Development Programme, 2017) including:

- Water quality degradation from multiple pollution sources;

- Decline in living marine resources from over-exploitation;

- Collapse in ecosystem integrity and loss of biodiversity;

- Habitat degradation and loss;

- Invasive species; and

- Climate change.

To support ecosystem-based management actions necessary for the sustainable use and development of LMEs, five modules and their associated indicator metrics serve as the primary source of data and information to inform strategic planning and implementation. These include natural science indicators for measuring LME (i) productivity, (ii) fish and fisheries, (iii) pollution and ecosystem health, as well as two social science metrics related to (iv) socioeconomics, and (v) governance (Sherman, 2005).

Governance in LMEs occurs at a variety of scales, and to achieve good ocean governance, coordination is required at all levels of implementation (Fanning et al., 2007; GEF LME:LEARN, 2018). At the local scale, LME governance acknowledges the need for community-based management and the importance of indigenous and local communities in cocreating sustainable environmental policy. At the national level, LME governance requires coordination between different ministries of the government and other stakeholder groups. On a regional scale, management becomes more complex and the focus is on cooperation among LME countries to manage pressing transboundary issues (GEF LME:LEARN, 2018).

Typically, an LME extends beyond the boundaries of two or more countries, and often these states find themselves locked in long-lasting and complex conflicts over marine resources. Continued depletion and degradation of the ocean and its coastal areas are most often attributed to failures in governance. As outlined by Duda (2016), difficulties in formulating, adopting, and implementing an appropriate governance system are not only a result of political considerations, but the variability and complexity of natural systems also play a role in the creation of fragmented governance frameworks. Thus, the articulation of practical ecosystembased approaches to ocean and coastal management are rare, particularly in a transboundary context. Since 1995, the Global Environment Facility (GEF) has provided financial support to the sustainable governance of twenty-three LMEs and has utilized a highly collaborative process as a major strategic planning tool for GEF International Waters Projects (Global Environment Facility [GEF], 2020).

The Transboundary Diagnostic Analysis (TDA)-Strategic Action Program (SAP) process (TDA-SAP process) enables countries to reach consensus on the priority transboundary issues and the actions required to address these via a joint LME project. The process facilitates a science-based strategy to monitor changing LME conditions by applying the five LME Approach modules. The TDA has a technical role in identifying, quantifying, and setting priorities for environmental problems that are transboundary in nature. Ultimately, it provides the scientific basis for the formulation of a SAP, a negotiated policy document endorsed at the highest level of all relevant sectors of government. The SAP then establishes clear priorities for action - such as policy, regulatory and institutional reforms and investments - to resolve the agreed upon transboundary issues identified in the TDA. A key element of a SAP is a well-defined baseline that enables a distinction between actions with national benefits and those where addressing transboundary concerns have global benefits (GEF IW:LEARN, 2020).

Together, the LME Approach and TDA-SAP process have helped foster a diversity of regional ocean governance mechanisms including formal conventions and commissions, protocols under existing Regional Seas Programs, improved coordination mechanisms, and other enhanced arrangements to mainstream ecosystem-based approaches. A considerable number of GEF International Waters projects have utilized these processes, and their success is a result of adapting this best practice methodology to the context and politics of the region. Just as each $\mathrm{LME}$ is unique, the resulting TDA and SAP are also unique. In this review, the diverse examples provided from the GEF International Waters portfolio emphasize this message by demonstrating how they have moved fragmented regional ocean governance toward an integrated, multistakeholder, ecosystem-based approach that nurtures, builds on, complements, and strengthens existing frameworks. These experiences also provide lessons that offer some insights on the shortfalls of and opportunities through these processes in achieving governance for LMEs. 


\section{REGIONAL COOPERATION TO SAVE THE BLACK SEA}

Almost cut off from the rest of the ocean, the Black Sea is one of the most isolated and exceptional regional seas globally (United Nations Development Programme, 2011). Its only connection is through the Bosphorus strait, a $35 \mathrm{~km}$ natural channel carrying $300 \mathrm{~km}^{3}$ of seawater to the Black Sea from the Mediterranean along the bottom layer, and returning a mixture of seawater and freshwater twice the volume in the upper layer (United Nations Development Programme, 2007a). Approximately $350 \mathrm{~km}^{3}$ of river water enters the Black Sea annually, including flows from the Danube, Dnipro, Don, and Dniester river basins (United Nations Development Programme, 1997).

Little to no action had been taken to protect the Black Sea prior to the 1990s due to the lack of knowledge of the environmental situation and political differences during the Soviet era (United Nations Development Programme, 2007a). The Black Sea experienced unprecedented degradation when widespread nutrient loading caused a large dead zone (Van Lavieren and Hanneke, 2015). Eutrophication led to radical changes in the ecosystem with major impacts on biological diversity and use of the sea, including recreation and fisheries (Van Lavieren and Hanneke, 2015). All countries comprising the Black Sea basin contributed to its near demise, emphasizing a strong need to harmonize legal and policy objectives and develop common strategies (United Nations Development Programme, 2007a).

A first decisive step toward a cooperative framework was taken in 1992 when representatives from Bulgaria, Georgia, Romania, Russia, Turkey, and Ukraine drafted the "Convention on the Protection of the Black Sea against Pollution", which was signed in Bucharest (Convention on the Protection of the Black Sea Against Pollution, 1992; United Nations Development Programme, 1997). Entering into force in 1994, it includes a basic agreement and several protocols aimed at controlling land-based sources of pollution, dumping of waste, joint actions in response to accidents, and biodiversity and landscape conservation (Black Sea Commission, 2009). To set the goals, priorities, and timeline needed to bring about action, a Ministerial Declaration on the Protection of the Black Sea Environment was signed in 1993 by all six Ministers of the Environment in Odessa (Odessa Ministerial Declaration on the Protection of the Black Sea, 1993), under the stewardship of the United Nations Environment Program (UNEP). From the outset, the Declaration was seen as an interim policy arrangement, with its signatories calling upon the GEF partners to assist with developing a medium to long-term action plan for the protection of the Black Sea (United Nations Development Programme, 1997).

Building upon this momentum, a proposal was presented to the GEF to financially support the three-year Black Sea Environmental Program (BSEP) launched with the support of the United Nations Development Program (UNDP) (United Nations Development Programme, 2004a). The overall objectives of BSEP were to improve the capacity of the Black Sea countries to assess and manage the environment, to support the development and implementation of new environmental policies and laws, and facilitate the preparation of sound environmental investments
(United Nations Development Programme, 1997). With the support of the Government of Turkey, the BSEP established itself in Istanbul. To spread the technical responsibilities of the program throughout the region, a system of Regional Activity Centers and Advisory Groups was created involving institutions from all six Black Sea countries (United Nations Development Programme, 1997). This enabled the program to bring together specialists who had not been able to cooperate previously, creating an environment for fresh and productive dialog (United Nations Development Programme, 2004a). Furthermore, the BSEP itself became a "label", serving an important function of making the various interventions coherent and attracting donor interest to the popular "Saving the Black Sea" cause (Black Sea Commission, 2009). The GEF project staff became de facto, the Secretariat for BSEP, which was an informal arrangement. This approach allowed staff from projects such as the EU's Tacis Black Sea to be seconded to the GEF project, and for the DirectorGeneral for the Environment of the European Commission to grant initial funding to the unit from 1999-2000 (United Nations Development Programme, 2004a).

The Program was also responsible for the development of the first Black Sea Transboundary Diagnostic Analysis (TDA) prepared by a group of sixteen leading specialists, drawn from fourteen countries (including all six Black Sea countries) together with five BSEP Program Coordinating Unit specialist staff (United Nations Development Programme, 2007a). Together they analyzed the thematic reports based upon the work of over a hundred Black Sea specialists cooperating through the BSEP network (Kinley, 2002). These represented some seventyfive national assessment reports and thirteen regional synthesis reports completed within the Program framework (Kinley, 2002), examining the root causes of Black Sea degradation and then proposing solutions (policy changes or capital investments).

Based on this TDA, high-level representatives of Black Sea governments were able to negotiate a very practical Black Sea Strategic Action Plan (BS-SAP), with the first draft completed by governmental representatives in June 1996 and submitted to intensive review at the national level (United Nations Development Programme, 1997). Following two further meetings, the refined draft was ready for submission to the Ministerial Conference in Istanbul on 31 October 1996 (Black Sea Commission, 2009). The BS-SAP was a groundbreaking document for the Black Sea region, establishing specific targets and timetables for implementing the objectives of the Bucharest Convention (Black Sea Ecosystem Recovery Project [BSERP], 2005). It contained fifty-nine specific commitments on policy regarding measures to reduce pollution, improve living resource management, encourage human development without prejudice to the environment, and to take steps toward improving the financing of environmental projects (United Nations Development Programme, 1996). With many of the Black Sea countries having numerous new legislation awaiting parliamentary approval, the BS-SAP took a pragmatic approach by recognizing the need to harmonize the objectives of these laws and regulations (United Nations Development Programme, 1997). Following the signing of the BS-SAP by the six Black Sea Environment Ministers, and to enable countries to complete 
National Black Sea Strategic Action Plans and for negotiations on the institutionalization of the Istanbul Commission's Secretariat to be completed, GEF funding was sustained, and additional support from the European Commission was committed to enable the implementation of the BS-SAP ${ }^{1}$ (United Nations Development Programme, 1997; Black Sea Commission, 2009).

After a protracted three-year process where the Black Sea countries worked on the technical and legal aspects of establishing a Secretariat, a breakthrough in the negotiations occurred, and the Black Sea Commission finally became operational in October 2000 (Black Sea Ecosystem Recovery Project [BSERP], 2005). Bulgaria, Romania, Turkey, and Ukraine made financial contributions to the Commission, and the Republic of Turkey provided the facilities for the Secretariat (Black Sea Commission, 2009).

In 2001, a Strategic Partnership was established through the GEF that brought together the Danube River Basin and the Black Sea (Black Sea Ecosystem Recovery Project [BSERP], 2005). These two water bodies and their key government, intergovernmental, donor, and civil society stakeholders formed an alliance to adopt a "basin-wide approach" to put in place sustainable systems of Danube and Black Sea management and governance. One component, the "Black Sea Ecosystem Recovery Project" (BSERP), was funded by the GEF and implemented by UNDP in partnership with UNEP and the United Nations Office for Project Services (UNOPS) (United Nations Development Programme, 2004a). A sister project for the Danube River Basin, "Strengthening Implementation Capacities for Nutrient Reduction and Transboundary Cooperation in the Danube River Basin," complemented and was closely coordinated with the BSERP (Van Lavieren and Hanneke, 2015). A third component of the Strategic Partnership under the World Bank involved a suite of ten nutrient reduction investments across the Danube/Black Sea countries (United Nations Development Programme, 2004a). Commencing in 2002, the BSERP aimed to support the regional aspects of the Black Sea Partnership for Nutrient Control and strengthen the role of the Black Sea Commission (United Nations Development Programme, 2004a). Under BSERP, the Black Sea Transboundary Diagnostic Analysis was revised and accepted in 2007 with the input of twenty-two experts from the Black Sea countries who collated verified scientific information (United Nations Development Programme, 2007a). The revised document was the factual basis for the formulation of the 2009 Black Sea Strategic Action Plan formally adopted in Sofia, Bulgaria (Black Sea Commission, 2009). The document embodied specific action (policy, legal, institutional reforms, or investments) that could be adopted nationally, within a harmonized multinational context, to address the major priority transboundary problems, and over the longer-term, restore or protect the Black Sea ecosystem (Black Sea Commission, 2009). By supporting countries to create an enabling environment for governance reform and investment, significant reductions in nutrient pollution occurred in the Black Sea (United Nations Development Programme, 2012b). Between 1988-1996, nitrogen

${ }^{1}$ The BS-SAP was amended on 14 June 2002, in Sofia (the Sofia Ministerial Declaration). loads to the Black Sea averaged at $36000(\mathrm{mt} / \mathrm{yr})$, and by 2005 this figure had significantly decreased to 25104 (mt/yr). Inorganic phosphorus loads into the Black Sea were between 10-20 (kt/yr) after the mid-nineties (Black Sea Commission, 2008), and dropped 5-6 (kt/year) up until 2002 (United Nations Development Programme, 2012b). Almost USD3 billion had been invested to address over two hundred nutrient pollution hot spots in the Black Sea and Danube River, the collective effort culminating in the recovery of the North West Shelf of the Black Sea from hypoxic conditions (United Nations Development Programme, 2012b). The highlighted results and unique lessons learned during the UNDP/GEF intervention from 1995-2009 are summarized in Table $\mathbf{1 .}$

\section{BENGUELA CURRENT COMMISSION: FROM PROJECT TO CONVENTION}

Flowing north-northwest from the Cape of Good Hope in South Africa and along the coast of Namibia before tapering off into Angola, the Benguela Current is one of the world's more powerful wind-driven coastal upwelling systems and one of the world's most productive marine ecosystems (Hamukuaya et al., 2016). Contributing almost US\$269 billion per annum in ecosystem goods and services, the long-term sustainability of the Benguela Current Large Marine Ecosystem is critical to the economic development and security of these three African countries (Van Lavieren and Hanneke, 2015).

During the 1960s and 1970s, an explosion of foreign fishing fleets began pillaging the waters of Angola, Namibia and South Africa, resulting in the severe depletion and collapse of several fish stocks such as hake, sardine and anchovy (United Nations Development Programme, 2001). This also coincided with the liberation struggles in all three countries and the associated civil wars, driving population migration to the coast. Consequences included localized pressure on marine and coastal resources, as well as an increase in localized bay pollution (United Nations Development Programme, 1999).

The three countries recognized a need to develop a viable joint and integrative mechanism for the sustainable environmental management of the region as a whole and move beyond their historical conflicts (United Nations Development Programme, 2000a). In 1995, during a workshop on Fisheries Resource Dynamics in the Benguela Current Ecosystem held in Swakopmund, Namibia, the foundations were laid for two extraordinary programs. The first was the Benguela Environment Fisheries Interaction \& Training Program (BENEFIT), which focused on capacity development and science and technology as applied to fisheries and the fish environment. During the workshop, participants were also inspired by the progress shared on the sustainable development of the Black Sea. This led to the countries requesting support from the GEF via UNDP to develop and implement the Benguela Current Large Marine Ecosystem (BCLME) Program (United Nations Development Programme, 2005). Complementary to BENEFIT, this program was a broadbased multi-sectoral initiative, aimed at sustainable integrated management of the Benguela Current ecosystem as a whole 
TABLE 1 | Highlighted results of the TDA-SAP process and LME Approach in the Black Sea as well as unique lessons learned from the intervention (United Nations Development Programme, 2007b; Fox and Buijs, 2008).

\begin{tabular}{|c|c|c|}
\hline $\begin{array}{l}\text { Timeframe of the } \\
\text { UNDP/GEF intervention }\end{array}$ & $\begin{array}{l}\text { Key governance related results } \\
\text { achieved/features in the SAP }\end{array}$ & Unique lessons learned and best practices \\
\hline
\end{tabular}

- Reviews of the legal, administrative and investment practices relating to eutrophication control to identify cost-effective alternatives were undertaken. The legal protocols governing pollution and resource use in the Black Sea were revised with new policies and laws for each coastal state;

- Support to the established Black Sea Commission was provided, including promotion of revised protocols and the development of new ones such as the new Fisheries Convention;

- Agricultural policies were reformed, industrial and municipal wastewater treatment improved, key basin ecosystems were rehabilitated, and the region's legislative framework and enforcement were strengthened;

- The establishment of a joint technical working group of the Black Sea and Danube Commissions enabled the development of a joint strategy on eutrophication and allowed the countries to pursue common targets

- The Black Sea SAP helped identify and map marine habitats and assess transboundary fish populations. It established conservation areas and secured the protection of marine mammals such as the highly endangered monk seal;

- Governments were assisted with water quality monitoring and collaborated with the private sector to draw up a contingency plan for oil spills.
- A well-managed and adequately funded Commission needs to be in place to take on the role of revising TDAs and SAPs, with donor funded projects playing a supporting role. Placing this responsibility outside of the established Commission runs the risk of lowering country ownership and responsibility;

- The revised TDA was a significant improvement over its predecessor, however it was perceived as a consultant driven exercise. Future TDA revisions were recommended to become part of the ongoing effort of the Commission and any subsidiary bodies;

- The Black Sea region had witnessed a significant reduction in support for marine sciences and regional research institutes. As such, projects like the BSERP became a critical lifeline for research on marine and riverine issues, emphasizing the importance of capacity building and training;

- During the first phase of the project, full time Country Team Leaders were hired in each of the six countries to help coordinate activities at the insistence of the participating countries. This strategic decision helped the involved Ministries and staff to follow through on expected commitments, especially in countries where there is little capacity to take on more obligations and budgets are not increased to cover in-kind contribution obligations;

- Exit Strategies are recommended to help countries focus on the eventual closure of a donor supported project and what they will do to sustain and replicate activities. The Exit Strategy developed by the BSERP and Black Sea Commission built on the institutional review of the Commission and provided considerations on how it could carry out its intended mission over short, medium and long term. Another key consideration is including recommendations for a phased transfer of financial responsibility from the donor funded project to the established Commission; - Institutional strengthening through donor funded projects need to ensure a high level of clarity regarding the relationship between the project and the established Permanent Secretariat. This relationship can become complicated, especially related to aspects such as the span of control and decision making authority on how budgets are allocated;

- Inter-ministerial coordination is important and should be part of the Project Document expectations, with commitments from all relevant ministries obtained prior to project approval.
(United Nations Development Programme, 1999). In 1998, a GEF grant was awarded to enable the development of a comprehensive project proposal and necessary Program instruments such as Thematic Reports, a Transboundary Diagnostic Analysis, and a Strategic Action Program (United Nations Development Programme, 1999, 2000a).

By 1999, the countries began preparatory work on the TDA that served to provide structured information relating to the social, economic and ecological status of the BCLME, with particular focus on transboundary impacts from anthropogenic actions (Hamukuaya et al., 2016). During a regional workshop in Windhoek, Namibia regional experts and international LME experts came together to draft the TDA and develop the framework of the SAP which outlined the regional policy for the integrated sustainable management of the BCLME. In January 2000, seven ministers from Angola, Namibia, and South Africa signed the SAP (United Nations Development Programme, 2001).

With the necessary Program instruments in place, the countries launched the five-year BCLME Program in 2003 (United Nations Development Programme, 2005). The Program provided a means for them to identify and resolve priority transboundary environmental problems at the LME level through long-term collaboration and partnership (Hamukuaya et al., 2016). The confidence and trust that grew between the three governments under the Program led to significant progress in the management of their shared marine resources. A central element of the SAP, and a key output of the Program, was the creation of the Benguela Current Commission (BCC). An Interim Agreement establishing the Commission was signed by South Africa and Namibia in August 2006 and by Angola in January 2007 (Van Lavieren and Hanneke, 2015). The permanent establishment of the BCC in 2008 constituted the first fully institutionalized and operational intergovernmental, multi-sectoral LME commission in the world (Benguela Current Commission, 2014). It was also the first ever inter-governmental commission based on the LME concept for ocean governance. This signified an important paradigm shift toward managing shared marine resources at a larger ecosystem level while balancing conservation obligations with human needs (Van Lavieren and Hanneke, 2015).

From 2011-2012 the countries worked together to finalize the content of the Benguela Current Convention that was signed March 2013, in the city of Benguela, Angola (Benguela Current Convention, 2013; Hamukuaya et al., 2016). This Convention effectively replaced the Interim Agreement, formally establishing 
the $\mathrm{BCC}$ as a permanent intergovernmental organization. By July 2014, the Convention had been ratified by all three countries (Benguela Current Commission, 2014), bringing it into force, and continuing to grow from strength to strength. The highlighted results and unique lessons learned during the UNDP/GEF intervention from 1998-2014 are summarized in Table 2.

\section{ESTABLISHING A PROTOCOL TO THE ABIDJAN CONVENTION IN SUPPORT OF THE GUINEA CURRENT LME}

Extending from the Bijagos Archipelago of Guinea-Bissau in the north to Cape Lopez on the coast of Gabon in the south, the Guinea Current Large Marine Ecosystem (GCLME) includes the exclusive economic zones of sixteen countries, namely, Angola, Benin, Cameroon, Congo, Côte d'Ivoire, Democratic Republic of the Congo, Equatorial Guinea, Gabon, Ghana, Guinea, Guinea Bissau, Liberia, Nigeria, Sao Tome and Principe, Sierra Leone and Togo (United Nations Development Programme, 2013a; United Nations Environment Programme, 2017). The region faces a number of challenges such as coastal erosion, habitat degradation, loss of biodiversity, overfishing, population growth and urbanization, public health and sanitation, and water pollution (United Nations Development Programme, 2013a). With several of the countries in the sub-region producing oil, the region is also threatened by oil pollution (Abe et al., 2016).

GEF support for the Gulf of Guinea LME began with the UNDP and United Nations Industrial Development Organization (UNIDO) pilot-phase project "Water Pollution Control and Biodiversity Conservation in the Gulf of Guinea Large Marine Ecosystem (LME)" (United Nations Development Programme, 1992). Implemented between 1995-1999 in collaboration with Benin, Cameroon, Cote d'Ivoire, Ghana, Nigeria, and later Togo, the project promoted greater cooperation between government authorities and institutions that were involved in water pollution control and habitat conservation activities (United Nations Development Programme, 1992). Toward the end of the pilot phase, a meeting of the Ministerial Committee of the GCLME took place in Accra, Ghana in July 1998. Eager to preserve the success of the pilot phase, the Ministers adopted the Accra Declaration on Environmentally Sustainable Development of the Large Marine Ecosystem of the Gulf of Guinea (Accra Declaration, 1998; United Nations Development Programme, 2013a). The Ministers called for the countries to support the continuation of the project as well as its extension to all sixteen littoral states of the LME. Furthermore, the communiqué issued afterward stated,

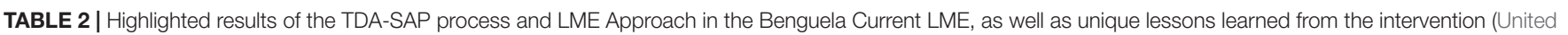
Nations Development Programme, 2008; United Nations Development Programme, 2012a).

\begin{tabular}{ll}
\hline Timeframe of the & Key governance related results achieved/features in the \\
UNDP/GEF intervention & SAP
\end{tabular}

UNDP/GEF intervention

- A landmark step for the Benguela Current LME was the establishment of the interim Benguela Current Commission as a prelude to the formal commission. Protection of the LME had been undermined by gaps in legal frameworks of the countries, especially the lack of laws regulating transboundary activities (i.e., marine mining and offshore petroleum exploration/production); - Establishment of the Africa LME Caucus;

- Capacity building and legislation started to reverse the threats of deteriorating water quality, invasion of alien species, declining fish stocks, and habitat destruction in the LME;

- New legislation on aquaculture were adopted by Angola and Namibia to encourage the development and quality of products, including shellfish production, and resulted in the development of an implementation plan for regional aquaculture policy options;

- All three countries adopted the MARPOL agreement and follow up actions included the development of a regional oil spill contingency plan project and monitoring systems were put in place to measure harmful algal blooms, temperature, salinity and oxygen;

- In 2005, Angola had rejected an agreement allowing EU vessels to fish in its waters, with the exception of Spanish vessels with 51\% Angolan ownership and under strict Angolan regulatory control and monitoring;

- By 2008, an Environmental Management Bill and the Pollution Control and Waste Management Bill were put up for debate in Namibia;

- Measures were adopted to reduce fisheries by-catch and reduce the impact of longline fishing on seabirds;

- Governments of the BCLME issued exploratory fishing licenses for stocks, which were previously not regarded as target species (e.g., clams, squid, jacopever).
- The use of a science-based approach to fundamental understanding of the ecosystem is essential, but should be complemented by management-orientated actions;

- The TDA/SAP cycle during the PDF-B phase was beneficial, but should be considered preliminary and reiterated during implementation of a donor funded project;

- A preliminary SAP was beneficial, but future SAPs should include a Vision Statement and Ecosystem Quality Objectives to help overcome imperfect country compliance with the priority actions laid out;

- In a first project phase, management changes are difficult to achieve and any such targets should be realistic and not included if in doubt;

- A strategic plan for capacity building should be undertaken at the TDA/SAP stage and should be designed to encourage national staff to stay in the system;

- Harmonization of national legal frameworks at the regional level had proven to be an unrealistic target. The BCLME project had influenced the development of fisheries legislation in Angola and environmental legislation in Namibia, indicating underlying policy convergence. The major challenge to harmonization, however; were the varying legal systems within countries. Thus, it was recommended that focus should be at the level of policy harmonization and cooperation through operational plans;

- Stakeholders had specific expectations in their own areas of interest in relation to policy actions of the SAP (i.e., mariculture regulations and policy, marine conservation plans). Throughout the evolution of the BCLME project, these expectations became more realistic and less ambitious over time. 
inter alia, "The development of a Strategic Action Program including a full Transboundary Diagnostic Analysis leading to the second phase of the project should be initiated and accelerated" (United Nations Development Programme, 2013a). In response, a request was submitted to the GEF through UNDP for a PDF Block B project preparation grant for the "Development of a Strategic Action Program for the Guinea Current Large Marine Ecosystem (GCLME)" project (United Nations Development Programme, 2006). Under the umbrella of the Abidjan Convention (Convention for Cooperation in the Protection and Development of the Marine and Coastal Environment of the West and Central African Region, 1981) and with the support of GEF, UNDP, UNEP, UNIDO, FAO, and the National Oceanic and Atmospheric Administration (NOAA) of the United States and other stakeholders, the project development was initiated in 2001.

By 2004, GEF funding was received for a full sized project titled "Combating Living Resources Depletion and Coastal Area Degradation in the Guinea Current Large Marine Ecosystem (GCLME) through Ecosystem-based Regional Actions" under the direction of UNDP and UNEP, in collaboration with UNIDO (Global Environment Facility [GEF], 2020). This foundational project, which ran until 2012, achieved major milestones for the GCLME, including the completion of the TDA in 2006 (United Nations Development Programme, 2006). In the same year, a Ministerial meeting reaffirmed regional commitment to the LME by institutionalizing cooperation under the Abuja Declaration (2006) and creation of a technical Interim Guinea Current Commission (IGCC) in the framework of the "Abidjan Convention" (Convention for Cooperation in the Protection and Development of the Marine and Coastal Environment of the West and Central African Region, 1981; United Nations Development Programme, 2013a). By 2007, the SAP had been completed and signed by government representatives of all the GCLME countries (United Nations Development Programme, 2007c). A second Ministerial meeting in July 2010 led to the Osu Declaration, reaffirming support for the creation of the Guinea Current Commission (GCC) and launching the consultation process for its creation. With the institutional structure established, a Regional Coordination Unit was in place to support the consultation and joint actions while also serving as the Executive Secretary of the IGCC (Humphrey and Gordon, 2012). By May 2012, a draft treaty for the establishment of the GCC had been prepared for discussion and decision making by the Ministerial Committee. This led to the Abidjan Declaration (2012), reiterating support for creation of a Guinea Current Commission and determining that this should be established through a protocol to the "Abidjan Convention" (Humphrey and Gordon, 2012). During the $12^{\text {th }}$ Conference of the Parties (COP12) of the Abidjan Convention, a resolution was adopted where the GCC should be operational by 2020 (United Nations Development Programme, 2013a). Through a new GEF funded project supported by UNEP, UNDP, FAO and UNIDO, the countries will continue to build on the policy direction of the SAP and address the remaining governance gaps related to establishing a permanent GCC (United Nations Environment Programme, 2017). The highlighted results and unique lessons learned during the UNDP/GEF intervention from 1995-2012 are summarized in Table 3.

\section{ENHANCING COORDINATION MECHANISMS IN THE CARIBBEAN AND NORTH BRAZIL SHELF LMES (CLME+)}

Jointly referred to as the CLME+, the Caribbean LME (CLME) and the North Brazil Shelf LME (NBSLME) are highly connected both biophysically and politically (United Nations Development Programme, 2014a). This extensive marine environment is characterized by globally significant levels of biodiversity that provide ecosystem services supporting livelihoods, human wellbeing and socio-economic development for the region and beyond (Debels et al., 2017). Two key drivers of the region's economy are tourism and fisheries, the latter supported by three distinct ecosystem types: the reefs and associated systems, the pelagic ecosystem, and the continental shelf ecosystem (United Nations Development Programme, 2014a). The capacity for these ecosystems to continue to provide goods and services has become increasingly impacted by environmental problems such as habitat degradation, unsustainable fisheries practices and pollution, all of which jeopardizes the region's opportunities for blue growth (United Nations Development Programme, 2014a).

According to Mahon et al. (2010), the CLME+ is one of the most geopolitically and biophysically complex marine regions in the world. In order to be prosperous and sustainable, any attempt at addressing the main threats to the region's marine ecosystems would require the cooperation of all forty-four countries and territories that have a stake in the CLME+ (United Nations Development Programme, 2016). The diversity of cultural, economic and geopolitical realities in the CLME+ has resulted in a largely fragmented approach to management and governance of the marine environment and key resources (United Nations Development Programme, 2014a).

The creation of a region-wide, cooperative governance framework through the use of the TDA-SAP process began with two phases of project development funding (PDF), first in 2001 as a PDF Block A Grant and then from 2006-2008 under a GEF PDF Preparatory Block B Grant (CLME, 2007). During the PDF $\mathrm{B}$ Phase, a preliminary analysis of the transboundary problems in the CLME was undertaken with the region sub-divided into Insular Caribbean, Central/South America and Guianas/Brazil (Whalley, 2011; Debels et al., 2017). The PDF-B phase highlighted the importance of effective governance to address sustainable use of living marine resources in the Wider Caribbean, and the need for a specific framework targeted at interventions to bring about the necessary change in regional fisheries governance (Mahon et al., 2011).

Recognizing that the condition of the Caribbean Sea required immediate attention and action, national governments successfully obtained GEF funding in 2009 and collaborated with the UNDP, UNOPS and the Intergovernmental Oceanographic Commission of the United Nations Educational, Scientific and Cultural Organization (IOC-UNESCO) to implement the 
TABLE 3 | Highlighted results of the TDA-SAP process and LME Approach in the Guinea Current LME, as well as unique lessons learned from the intervention (Humphrey and Gordon, 2012; United Nations Environment Programme, 2017).

\begin{tabular}{|c|c|c|}
\hline $\begin{array}{l}\text { Timeframe of the } \\
\text { UNDP/GEF } \\
\text { intervention }\end{array}$ & Key governance related results achieved/features in the SAP & Unique lessons learned and best practices \\
\hline 1995-2012 & $\begin{array}{l}\text { - More than one hundred environmental experts had been trained in drafting } \\
\text { and implementing common standards, policies and legislation; } \\
\text { - Integrated Coastal Area Management Plans were adopted by all } \\
\text { participating countries with national steering committees formed to guide } \\
\text { the process, and country coast profiles had been published; } \\
\text { - Port reception facilities were established in Nigeria, Ghana and Cote } \\
\text { D'Ivoire, enhancing ballast water management capacity; } \\
\text { - Industrial effluent regulations and standards had been established for the } \\
\text { region and were adopted and enforced by several countries. Best practice } \\
\text { in the reduction, recovery and recycling of municipal and industrial solid } \\
\text { waste in Ghana, had been extended to other countries of the GCLME; } \\
\text { - To conserve fisheries, a regulatory policy had been adopted with closed } \\
\text { and open seasons. The licensing of distant water industrial fishing fleets } \\
\text { was halted under the Accra Declaration, effectively reducing the extreme } \\
\text { pressure on fisheries resources from large commercial offshore fishing fleets } \\
\text { from the EU, Eastern Europe, Republic of Korea, and Japan; } \\
\text { - Since the creation of the Interim Guinea Current Commission, several key } \\
\text { partnerships had been forged and agreements entered into, including: } \\
\text { o Joint programming with the International Petroleum Industry } \\
\text { Environmental Conservation Association (IPIECA) on oil spill prevention and } \\
\text { response } \\
\text { o Coordination with the Gulf of Guinea Commission (GGC) on Security and } \\
\text { Socioeconomic development } \\
\text { o MoU for joint programming with the Fishery Committee for the West } \\
\text { Central Gulf of Guinea (FCWC) } \\
\text { o LOA with the International Maritime Organization (IMO) for ballast water } \\
\text { management and oil spill contingency planning } \\
\text { o MoU for joint programming with Regional Fisheries Committee for the Gulf } \\
\text { of Guinea (COREP). }\end{array}$ & $\begin{array}{l}\text { - While the role of the Regional Coordination Unit (RCU) to } \\
\text { serve as the Secretariat for the Interim Guinea Current } \\
\text { Commission (IGCC) was strategically a means to save funds } \\
\text { and provide the platform for sustaining results achieved, the } \\
\text { dual role created a false sense of security in the financial } \\
\text { support for the Commission and created confusion in terms } \\
\text { of accountability. While the RCU was in a good position to } \\
\text { champion the future Guinea Current Commission, playing an } \\
\text { impartial facilitation role was difficult; } \\
\text { - A key lesson from the GCLME projects of relevance to other } \\
\text { regional initiatives is to ensure a clear independence between } \\
\text { the project and the institutional mechanisms they are trying to } \\
\text { create. However, it is important to remember that the } \\
\text { relationship between the two can be expected to differ on a } \\
\text { case by case basis; } \\
\text { - Despite strong political support, country ownership can } \\
\text { become weakened if there is lack of empowerment of } \\
\text { national structures. Inter-Ministerial Committees played an } \\
\text { active role in developing and endorsing the national plans of } \\
\text { action on land-based sources of marine pollution (NPAs-LBS) } \\
\text { and National Programs of Action (NAP), however the difficulty } \\
\text { of maintaining consistent representation compromised their } \\
\text { mainstreaming role; } \\
\text { - While there was little evidence of national policy changes in } \\
\text { key sectors such as fisheries, pollution, and habitat } \\
\text { management, the SAP and NAP, legal studies, NPAs on } \\
\text { land-based sources, and sectoral plans paved the way for } \\
\text { future actions. }\end{array}$ \\
\hline
\end{tabular}

Caribbean Large Marine Ecosystem Project. The Project aimed to help the countries and territories in the region unite their efforts to establish a more coordinated ecosystem-based approach to management (United Nations Development Programme, 2009a). In 2010, in a meeting between the Technical Task Team and Stakeholder Advisory Group it was agreed that an updated TDA should focus on the three ecosystems representing the key types of fisheries of the CLME (reef, pelagic and continental shelf fisheries ecosystems) as coastal and marine fisheries take place in one of these ecosystem types (Whalley, 2011). Under the Project, four TDA reports were prepared: Reef and Pelagic Fisheries TDA, Continental Shelf Fisheries TDA, Regional TDA, and a Governance TDA (United Nations Development Programme, 2014a). The three priority environmental problems, highlighted through these TDAs and common to the three ecosystem subtypes, were: (1) unsustainable exploitation of fish and other living resources; (2) habitat degradation and ecosystem community modification; and (3) pollution. The causal chain analysis conducted under the Project identified weak cross-sectoral governance arrangements as the overarching root cause of the transboundary problems affecting the CLME and adjacent regions (United Nations Development Programme, 2014a). The results of these TDAs were combined with the knowledge and insights from case studies and pilot projects to produce the Strategic Action Program for the Sustainable Management of the Shared Living Marine
Resources of the Caribbean and North Brazil Shelf Large Marine Ecosystems (United Nations Development Programme, 2013b). The countries of the CLME+ region approved the ten-year SAP that had an initial focus on governance and management of shared living marine resources. The cooperation between the Caribbean Regional Fisheries Mechanism (CRFM) and the Central America Fisheries and Aquaculture Organization (OSPESCA) under a signed Memorandum of Understanding in 2012, and the development of an Oceans Governance Policy by the Organization of Eastern Caribbean States (OECS) were important milestones that complemented and supported the SAP (Debels et al., 2017). The highly participatory process during the development of the SAP facilitated national and regional-level ownership of its content and priorities (Debels et al., 2017). By 2014, thirty-one Ministers in twenty-two countries had endorsed the SAP, making it the most widely endorsed Action Program within the GEF International Waters Focal area (United Nations Development Programme, 2016).

The SAP provides the region with an integrative, formal "umbrella" framework for action that enables information exchange and cooperation among the various active initiatives and projects taking place within the CLME+, ultimately leading to enhanced coordination and decision-making (United Nations Development Programme, 2014a). To achieve this, a regional governance framework of consolidated, inter-linked and complementary organizations was suggested (Debels et al., 
2017). This nested and multi-level approach would allow regional and sub-regional organizations with existing mandates for dealing with the identified transboundary threats to be further strengthened via the framework, and enables stakeholders to identify their roles and interactions needed with one another for effective governance (Debels et al., 2017).

To catalyze the implementation of the CLME+ SAP, a five year GEF financed and UNDP supported CLME+ Project was initiated in 2015. By July 2017, the Project had formally established an Interim Coordination Mechanism (ICM) for the CLME+ region through the signature of an $\mathrm{MoU}$ by five regional intergovernmental organizations including the Organization of the Central American Fisheries and Aquaculture Sector (OSPESCA), the Caribbean Community (CARICOM) Secretariat, the Caribbean Regional Fisheries Mechanism (CRFM), the Central American Commission for Environment and Development (CCAD), and the Organization of Eastern Caribbean States (OECS) Commission (CLME+ PROJECT, 2017). The Western Central Atlantic Fisheries Commission of the UN Food and Agriculture Organization (UN FAO-WECAFC), the IOC Sub-Commission for the Caribbean and Adjacent Regions (IOCARIBE), and UNEP represented by its Caribbean Regional Coordinating Unit and Secretariat to the Cartagena Convention subsequently joined the ICM (CLME+ PROJECT, 2017). The ICM has been at the heart of the CLME+ Alliance and Partnership that is aiming to unite academia, civil society, donor and development community, governments, and the private sector, in a shared mission to safeguard the CLME+ region (CLME+, 2020a).

In June 2020, a milestone decision for the Wider Caribbean was reached on the proposed long-term regional "Ocean Governance" Coordination Mechanism in a response to a call for action under the CLME+ SAP. During a steering committee meeting of the GEF/UNDP CLME+ Project, more than twenty countries and fourteen organizations from the Wider Caribbean laid the foundations for the Coordination Mechanism and reached an agreement on its core aspects (CLME+, 2020b). The subsequent Special Session which took place in October 2020 enabled the countries and regional organizations to make substantial progress on the text for the MoU through which the Coordination Mechanism will be created, and at the time of writing further negotiations were ongoing with the aim of achieving formal endorsement of the Coordination Mechanism in early 2021 (CLME+, 2020b). The highlighted results and unique lessons learned during the UNDP/GEF intervention since 2001 are summarized in Table 4.

\section{BUILDING UPON INTERGOVERNMENTAL ARRANGEMENTS IN THE WESTERN TROPICAL PACIFIC WARM POOL LARGE MARINE ECOSYSTEM}

Covering over ten percent of the Earth's surface, the waters of the Pacific Islands region hold the world's largest stocks of tuna and related pelagic species (Pacific Islands Forum Fisheries Agency [FFA], 2018). Most of this area falls within the national jurisdiction of fifteen Pacific Small Island Developing States (SIDS), making them the custodians of a major international waters ecosystem (United Nations Development Programme, 2004b). The defining physical feature of this water body is the Western Tropical Pacific Warm Pool Large Marine Ecosystem (WTP LME). While the WTP is not always identified as an LME, it shares the major characteristics that define LMEs (United Nations Development Programme, 2004b). The importance of these waters in environmental and geographical terms is enhanced by the significance of the management aspects where the Pacific SIDS have developed a degree of cooperation that are globally important (United Nations Development Programme, 2004b).

At the center of this cooperation lies the concern over global, regional, and transboundary fish stocks. These stocks are highly migratory and have ranges extending the jurisdiction of twenty countries and into large areas of the high seas (United Nations Development Programme, 2011). Wherever these stocks occur, countries have a responsibility under international law to adopt measures for their management and conservation (United Nations Development Programme, 2012a). Without a coherent and legally binding framework to establish and apply measures, unregulated fishing and inconsistent measures in various national zones undermines the efforts of individual countries (United Nations Development Programme, 2004b).

The people of the Pacific Islands have always applied practices aimed at conservation of marine resources (United Nations Development Programme, 2004b). When stock assessments in the 1980's revealed that tuna stocks of the region were the largest in the world, it was only a matter of time before markets and technology would drive fishing to unsustainable levels (United Nations Development Programme, 2011). In 1990, the Pacific Island Countries decided to prepare a joint regional position to the 1992 United Nations Conference on Environment and Development (UNCED). The Conference provided the first opportunity for the Islands to gather information, analyze the results and build regional consensus on integrating environmental and developmental concerns into a sustainable whole, using their knowledge and experience gained in the twenty years since the Stockholm Conference on the Environment (South Pacific Regional Environment Programme, 1997; United Nations Development Programme, 2004b).

During a regional training and scoping workshop co-financed by the GEF in 1995, the UNDP together with the Secretariat of the Pacific Regional Environment Program (SPREP) and the Government of Australia agreed to develop a regional proposal for the preparation of a SAP. Following further regional and national consultation, the proposal was approved in 1997 (Tortell and Tarte, 2004). The SAP identified weaknesses in the extent to which decision-makers were able to access information necessary to understand the causes of unsustainable actions, and to respond to imminent threats. The lack of appropriately presented strategic information hindered decision-makers, resource users, managers and communities in evaluating the cost and benefits of alternative activities and to decide the best course of action 
TABLE 4 | Highlighted results of the TDA-SAP process and LME Approach in the Caribbean LME, as well as unique lessons learned from the intervention (United Nations Development Programme, 2016; Merla, 2018).

\begin{tabular}{|c|c|c|}
\hline $\begin{array}{l}\text { Timeframe of the } \\
\text { UNDP/GEF intervention }\end{array}$ & $\begin{array}{l}\text { Key governance related results achieved/features } \\
\text { in the SAP }\end{array}$ & Unique lessons learned and best practices \\
\hline 2001- Ongoing & $\begin{array}{l}\text { - At a sub-regional level, the Caribbean Regional } \\
\text { Fisheries Mechanism of the Caribbean Community } \\
\text { (CRFM-CARICOM) and the Organization of the } \\
\text { Fisheries and Aquaculture Sector of the Central } \\
\text { American Isthmus (OSPESCA) of the Central American } \\
\text { Integration System (SICA) subscribed a Joint Action } \\
\text { Plan signed by ministers from nineteen countries to } \\
\text { promote the implementation of an ecosystem approach } \\
\text { across highly important regional fisheries (lobster, queen } \\
\text { conch, and large pelagics); } \\
\text { - The Southwest Cay on the Pedro Banks in Jamaica } \\
\text { was declared a Special Fish Conservation Area, and a } \\
\text { Strategic Zoning and Fisheries Management Plan was } \\
\text { completed for the Montecristi National Park of the } \\
\text { Dominican Republic; } \\
\text { - The Ministerial Forum of the Caribbean Regional } \\
\text { Fisheries Mechanism approved the first transboundary } \\
\text { fishery management plan to be adopted in the } \\
\text { CLME+ region (a Sub-regional management plan for } \\
\text { the Eastern Caribbean Flyingfish Fishery); } \\
\text { - Caribbean fisheries ministers adopted an urgent action } \\
\text { plan to save Caribbean coral reefs in collaboration with } \\
\text { climate change and fisheries agencies within the } \\
\text { Caribbean Community; } \\
\text { - To engage and empower civil society and private sector } \\
\text { stakeholders in implementation of the CLME+ SAP, a } \\
\text { complimentary CLME+ Civil Society Action Program } \\
\text { (C-SAP) was developed in collaboration with the } \\
\text { Caribbean Natural Resources Institute (CANARI); } \\
\text { adopted by Fisheries and Aquaculture Ministers of the } \\
\text { Central American Integration System member states. }\end{array}$ & $\begin{array}{l}\text { - The results of a Governance Effectiveness Assessment indicates that } \\
\text { there is room for greater regional collaboration when developing } \\
\text { issue-specific policies. Furthermore, expanding collaborative } \\
\text { development and implementation of governing instruments (e.g., } \\
\text { coordinating mechanisms) at the regional level could foster a more } \\
\text { consistent approach to addressing interconnected issues; } \\
\text { - More information is necessary to accurately assess the stressors } \\
\text { exerted on the marine environment to determine which of these should } \\
\text { be tracked to better inform SAP decision making; } \\
\text { - The interim Coordination Mechanisms established by the } \\
\text { CLME+ project are examples of best practices for: } \\
\text { o Successfully achieving actions set out under the CLME+ SAP } \\
\text { strategies, especially those which focus on integrated and coordinated } \\
\text { regional ocean governance; } \\
\text { o Building trust and enabling coordinated actions among regional } \\
\text { Intergovernmental Organizations and other stakeholders; } \\
\text { o Enabling the creation of a long-term coordination mechanism for } \\
\text { continued support of integrated ocean governance; } \\
\text { o Coordinated support for achieving regional and international goals } \\
\text { and targets (e.g., SDG14, Aichi) across the region; } \\
\text { - Improved collaboration and coordinated communication between } \\
\text { Coordination Mechanism members; } \\
\text { - Supporting and strengthening national level coordination. } \\
\text { governmental/public sector perspective. However, successful } \\
\text { governance of the region's shared living marine resources also } \\
\text { interfaces. Understanding how they are structured and how they work } \\
\text { would be very beneficial to the science community, especially for } \\
\text { influencing policy decisions. }\end{array}$ \\
\hline
\end{tabular}

(United Nations Development Programme, 2004b). The SAP also identified weaknesses in governance at both the regional and national levels. A critical regional weakness was the paucity of legally binding institutional arrangements governing cooperation in the management of the region's commercial oceanic fisheries (South Pacific Regional Environment Programme, 1997). While there had been a high level of voluntary cooperation between Pacific SIDS there was not a formal collaborative process covering the range of the major stocks. At the national level, weaknesses in governance included lack of compatible management arrangements between zones, lack of political commitment to take hard decisions to limit fishing and catches, and a lack of capacity (South Pacific Regional Environment Programme, 1997).

To explore ways of addressing the threats identified in the SAP, the GEF funded and UNDP implemented "Implementation of the Strategic Action Program (SAP) of the Pacific Small Island Developing States" project was established. Operational from 2000-2004, the project had two major components, Integrated Coastal and Watershed Management (ICWM) and Oceanic Fisheries Management (OFM). Inter alia, the OFM component supported the Pacific Island countries in the negotiation of the
Western and Central Pacific Fisheries Convention (Convention on the Conservation and Management of High Migratory Fish Stocks in the Western and Central Pacific Ocean, 2004; Tortell and Tarte, 2004). The Convention was one of the first major regional applications of the 1995 UN Straddling Fish Stocks Agreement (United Nations Development Programme, 2012a). The development of the Convention was supported through a process coordinated by the Pacific Island Forum Fisheries Agency (FFA) that facilitated direct dialog between the Pacific SIDS, coastal states, and fishing states (United Nations Development Programme, 2011). Initiated by an invitation from Pacific Island leaders, stakeholders came together to discuss enhanced arrangements for managing the impact of fishing. Finalizing the Convention text required another thirteen meetings with all Pacific SIDS participating in all sessions, as well as a series of ad hoc dialogs with other fishing states (United Nations Development Programme, 2004b). The Convention entered into force on 19 June 2004, with twelve of the thirteen required ratifications being from Pacific SIDS, and brought into being the last of the tuna Regional Fisheries Management Organizations (RFMOs), the West and Central Pacific Fisheries Commission (United Nations Development Programme, 2011). In December 
of the same year, a Western and Central Pacific Fisheries (WCPF) Preparatory Conference was established to prepare the foundation for the new WCPF Commission (United Nations Development Programme, 2004b). During the Conference, the rules of procedures and the organizational structure of the Commission had been formally adopted. Working via the FFA during 2005 to 2011, the subsequent GEF supported "Pacific Islands Oceanic Fisheries Management" Project guided the final stages of establishing the new Commission, determining how it will work, and the initial period of operation (United Nations Development Programme, 2011). It also supported Pacific SIDs' efforts to reform, realign, restructure and strengthen their national fisheries laws, policies, institutions, and programs to take up the opportunities that the WCPF Convention created, and undertake the responsibilities outlined under the SAP (Hanchard, 2011). By 2011, the Commission was ratified by thirty-three of the thirty-four States and Territories that participated in the process (Hanchard, 2011; United Nations Development Programme, 2012a).

Following this success and commencing in 2014, the GEF supported a second project titled "Implementation of Global and Regional Oceanic Fisheries Conventions and Related Instruments in the Pacific Small Island Developing States". Overseen by UNDP and FAO, and again managed by the FFA, the project focused on implementation of the work and activities of the Commission and its related instruments with additional key components supporting important SPC research into the impacts of climate change on tuna fisheries and the oceanic ecosystem (United Nations Development Programme, 2014b). Some key of the project activities have been delivered by providing support to important and influential regional entities, the most significant being the Office of the Parties to the Nauru Agreement (PNA) which entered into force in 1982 and utilizes a market-based mechanism (Vessel Day Scheme auctioning fishing days) to allocate sustainable levels of fishing activity across the purse seine fishery (United Nations Development Programme, 2014b).

The project has also supported important capacity building and human development activities across regional, subregional and national platforms (United Nations Development Programme, 2011). This has included a diverse range of training, workshops and meetings including the annual FFA Monitoring, Control and Surveillance Workshop (MCSWG) which sets the tone for the Regional MCS strategy and the very strategic annual Management Options Consultation (MOC) during which FFA Members consider priority matters for consideration by the annual session of the Western and Central Pacific Fisheries Commission and also the strategies to adopt in pursuing the agreed priorities in the course of the WCPFC meeting (United Nations Development Programme, 2011).

In 2014, Leaders of the Pacific Islands Forum endorsed a Pacific Vision for a region of harmony, peace, prosperity, security, and social inclusion (United Nations Development Programme, 2014b). The Framework for Pacific Regionalism (FPR) represents a long-term commitment to deeper regionalism as a means to achieve this vision. Strongly aligned with fisheries priorities under this Framework, the Project contributes to the annual progress reporting through Report Cards on Tuna Fisheries and Coastal
Fisheries to help fisheries managers meet the goals of the Regional Roadmap for Sustainable Pacific Fisheries (United Nations Development Programme, 2014b). A significant milestone of these efforts was demonstrated in the 2019 results of the Tuna Report Card on the state of health of tuna fisheries, which reported that all four species of economic importance in the region (skipjack, South Pacific albacore, yellowfin, and bigeye) are being fished sustainably (Pacific Islands Forum Fisheries Agency [FFA], 2019). The highlighted results and unique lessons learned during the UNDP/GEF intervention since 1997 are summarized in Table 5.

\section{TRANSFORMING THE YELLOW SEA LARGE MARINE ECOSYSTEM}

The Yellow Sea is a semi-enclosed body of water bounded by the Chinese mainland to the west, the Korean Peninsula to the east, and a line running from the north bank of the mouth of the Yangtze River to the south side of Jeju Island (United Nations Development Programme, 2014c). For the purposes of defining the Yellow Sea LME project boundaries, the northwestern extent is a line drawn in a northeasterly direction from Penglai on the Shandong Peninsula to Lvshun of Dalian of People's Republic of China (PR China) (Lenoci and Shuo, 2020). According to United Nations Development Programme (2014c), this international water-body supports substantial populations of invertebrates, fish, mammals, and water birds. These resources have been threatened by habitat loss from extensive economic development in the coastal zone, pollution, and by unsustainable exploitation of natural resources such as overfishing (United Nations Development Programme, 2012b). Additionally, there are threats from oil spills and collisions with marine mammals due to significant international shipping traffic through the waters of the Yellow Sea (United Nations Development Programme, 2014c).

Driven by their common concern for the Yellow Sea LME, PR China and the Republic of Korea (RO Korea) recognized the urgent need to address problems of reduced fish catches, red tide outbreaks, degradation of coastal habitats, and marine pollution through regional cooperation. Early concepts supporting the Yellow Sea Large Marine Ecosystem (YSLME) were the result of meetings held in 1992, sponsored by the World Bank and NOAA (United Nations Development Programme, 2007d). During the ensuing years, a PDF-B project was supported by the GEF under UNDP's implementation. In August 1999, the first Steering Committee Meeting was held in Beijing, PR China (United Nations Development Programme, 2002). Later that year, RO Korea and PR China completed first drafts of their National Reports, which formed part of the technical basis for the PDFB outputs (United Nations Development Programme, 2002). By 2000, a preliminary TDA (PTDA) was prepared as part of the Project Preparation exercise (United Nations Development Programme, 2007d). The PTDA provided background material for a Project Brief and a forum for consensus building on the environmental issues of highest priority in the Yellow Sea (United Nations Development Programme, 2000b). In 2005, the launch 
TABLE 5 | Highlighted results of the TDA-SAP process and LME Approach in the Western Tropical Pacific Warm Pool LME, as well as unique lessons learned from the intervention (Tortell and Tarte, 2004; United Nations Development Programme, 2011; Chapman and Fong, 2018).

\begin{tabular}{|c|c|c|}
\hline $\begin{array}{l}\text { Timeframe of the } \\
\text { UNDP/GEF } \\
\text { intervention }\end{array}$ & Key governance related results achieved/features in the SAP & Unique lessons learned and best practices \\
\hline 1997- Ongoing & $\begin{array}{l}\text { - Facilitated the full participation of Pacific Island States as primary stakeholders } \\
\text { in the negotiation and development process for the Convention and } \\
\text { Commission for the Conservation and Management of Highly Migratory Fish } \\
\text { Stocks in the Western and Central Pacific; } \\
\text { - Supported fifteen Pacific SIDS in conducting reviews of the legal, policy, and } \\
\text { institutional arrangements, their national fisheries status, and management } \\
\text { plans relating to the Convention; } \\
\text { - Supported the adoption and implementation by the WCPFC and the Pacific } \\
\text { SIDS a range of innovative measures to promote sustainable fisheries, including: } \\
\text { - The largest rights-based cap and trade management scheme in international } \\
\text { fisheries (the Parties to the Nauru Agreement purse seine vessel day scheme); } \\
\text { - Seasonal closures on fishing on floating rafts (FADs) to reduce by-catches; } \\
\text { - A 30\% reduction in catches of vulnerable bigeye tuna by major longline fleets; } \\
\text { - Large scale high seas closures to purse seine fishing vessels; } \\
\text { - Compulsory retention of catches of major tuna species; } \\
\text { - Measures to reduce shark finning; } \\
\text { o Ban on setting on whale sharks; } \\
\text { o Mitigation of by-catches of turtles and seabirds; } \\
\text { o The largest on-board observer program including one hundred percent } \\
\text { coverage on tropical purse seine vessels; } \\
\text { - The only high seas boarding and inspection program in global tuna fisheries; } \\
\text { - World's largest international satellite-based vessel tracking (over two } \\
\text { thousand high seas tuna vessels) }\end{array}$ & $\begin{array}{l}\text { - Small Island Developing Countries can make a difference } \\
\text { by working together; } \\
\text { - Regional conservation measures and resource protection } \\
\text { programs have improved the investment climate in oceanic } \\
\text { fisheries - limits are good for business; } \\
\text { - Long term investments in science and data pay off; } \\
\text { - Monitoring and control programs create attractive jobs; } \\
\text { - There is a critical need for long term capacity building which } \\
\text { goes beyond the scope of donor funded projects; } \\
\text { - Promoting the donor projects and their outcomes to } \\
\text { individuals in foreign affairs, legislation, and government has } \\
\text { a greater pay-off than focusing outward to create } \\
\text { awareness and recognition; } \\
\text { - This case study demonstrates an example where a new } \\
\text { commission with ecosystem-based requirements can } \\
\text { complement an older regional seas convention on } \\
\text { environment (the Noumea Convention); } \\
\text { - It could be argued that a strain is placed on countries to } \\
\text { provide funding for a new commission, however; increased } \\
\text { fees for licenses for distant fleets catching tuna, LME } \\
\text { management, and some added national programs were } \\
\text { paid for by the user (Hudson and Glemarec, 2012). }\end{array}$ \\
\hline
\end{tabular}

of the full sized "Reducing Environmental Stress in the Yellow Sea Large Marine Ecosystem" project under the support of the GEF and UNDP enabled participating countries to undertake a step-wise process by focusing on the preparation and completion of the region's, National Strategic Action Plans (NSAPs), and the first SAP (United Nations Development Programme, 2007d). The SAP was endorsed in 2009 by both countries, while the Democratic People's Republic of Korea (DPR Korea) supported as an observer, and served as a common regional framework with eleven regional targets and thirty-two management actions to be achieved by 2020 (United Nations Development Programme, 2009b). The proposed management actions included not only technical actions, but also governance actions. Specifically, the SAP suggested improving the effectiveness of legal instruments, to promote participation of a wide range of stakeholders, and to create an YSLME Commission (United Nations Development Programme, 2009b).

Following this highly successful phase I Project that ended in 2011, a second GEF funded project titled "Implementation of the Yellow Sea LME Strategic Action Program for Adaptive Ecosystem-Based Management" was approved by the Government of PR China, UNDP and UNOPS in July 2014 which was operational from 2017 until December 2020 (United Nations Development Programme, 2014c). Within the overall period of the two GEF-financed projects, important stress reduction achievements were demonstrated by the two YSLME countries. Under the SAP, tangible targets on reducing fishing efforts were agreed, including reducing $30 \%$ of the fishing boats. Guided by PR China’s five-year plan (2015-2020), about $22 \%$ of fishing vessels were reduced in the provinces of Liaoning, Shandong and Jiangsu in the Yellow Sea area by 2018 (United Nations Development Programme, 2020). In addition, RO Korea's five-year plan on reduction of fishing vessels showed a 17\% decrease from 2011-2017. The countries had also committed to increasing the total area of critical habitats as Marine Protected Areas (MPAs) by 3\%. From 2009 to 2019, the MPA areas in PR China and RO Korea grew from 2,051,366 ha to $2,210,741$ ha, representing an increase of $5.52 \%$ of the total areas of the Yellow Sea (United Nations Development Programme, 2020). The governments of the participating countries also agreed to reduce pollution levels and improve water quality in the YSLME. By undertaking monitoring activities in line with the countries' policy frameworks on marine pollution management, a significant decrease in marine litter has been reported as a result of improved practices in both countries. From 2010 to 2018, PR China saw a decrease in the density (items $\left./ \mathrm{km}^{2}\right)$ in both floating macro $(>10 \mathrm{~cm})$ and meso $(<10 \mathrm{~cm})$ litter in the surface water. From 2010 to 2017, the mean density of benthic litter of monitoring sites was about 130 items $/ \mathrm{km}^{2}$ (United Nations Development Programme, 2020). By 2018, the density of benthic litter (primarily plastics), in the monitoring sites of the Yellow Sea was 75 items $/ \mathrm{km}^{2}$. Similarly, RO Korea reported a decreasing temporal trend of distribution of macro debris, indicating that the number, weight and volume decreased significantly along the coastline in the 10-year period (20082017). To control coastal pollution and improve water quality (COD level), RO Korea implemented a Total Pollution Load Management System for special management areas, including Sihwa Lake located within the LME. As a result, the water quality improved, showing a decrease in pollutant levels by 
15\% (United Nations Development Programme, 2020). Based on the 2007 TDA, one of the major environmental problems was the enrichment of nutrients in the Yellow Sea, and the major cause of harmful algal blooms (HABs) in the region (United Nations Development Programme, 2020). Through the SAP implementation project interventions, outbreaks of Ulva bloom in Qingdao, PR China have become less frequent and a decrease in the Maximum Distribution Area and Maximum Covering Area of Green Tide was reported from 2013 to 2017. In RO Korea, the number of HAB occurrences declined from 2014 with no red tide occurrence in 2016 and 2017 (United Nations Development Programme, 2020).

In December 2020, PR China and RO Korea agreed on the text for the Memorandum of Understanding (MoU) to establish the regional governance mechanism for the YSLME responsible for coordinating the implementation of the YSLME SAP 2020-2030 (Yellow Sea Large Marine Ecosystem, 2020), demonstrating the commitment of the countries for continuity and strengthening their cooperation for the future of the YSLME (Lenoci and Shuo, 2020). The highlighted results and unique lessons learned during the UNDP/GEF intervention from 1999-2020 are summarized in Table 6.

\section{SHORTCOMINGS OF THE PROCESS AND COMMON LESSONS LEARNED}

The contribution of the TDA-SAP Process and LME Approach toward achieving regional ocean governance is not without controversy or critique. Bensted-Smith and Kirkman (2010) led an analysis commissioned by Conservation International and concluded that LME projects funded by the GEF should invest in strengthening Regional Seas Programs and building links between institutions, as opposed to creating additional commissions. This finding was supported by a study commissioned by UNEP, where Rochette et al. (2015) found that a primary weakness of the LME Approach and TDA-SAP process was the absence of linkages to existing arrangements, decreasing the chances of sustainability and minimal uptake of the contributions made. Additionally, Fanning et al. (2015) identified that the spatial fit between LMEs and overlapping regional ecosystem-orientated arrangements were poor. More recently, a review undertaken by the United Nations Development Programme (2017) identified several factors that have impeded the effectiveness of the TDA-SAP Process and LME Approach, which include:

- Earlier TDA-SAP and LME Approach projects did not include civil society or the private sector at the early stages of development, stakeholders who should actively contribute to ocean governance measures;

- A test of sustainability is evaluating what elements of donorfunded project outcomes persist once the project has been completed and/or funding has ceased. A shortfall of the TDA-SAP process lies within the financial arrangements laid out post donor assistance. While there have been remarkable successes in LME management, stakeholders still perceive the award of a donor grant for continued support as a mark of "sustainability". As identified in the

TABLE 6 | Highlighted results of the TDA-SAP process and LME Approach in the Yellow Sea LME, as well as unique lessons learned from the intervention (United Nations Development Programme, 2012a; Lenoci and Shuo, 2020).

\begin{tabular}{|c|c|c|}
\hline $\begin{array}{l}\text { Timeframe of the } \\
\text { UNDP/GEF intervention }\end{array}$ & $\begin{array}{l}\text { Key governance related results achieved/features in } \\
\text { the SAP }\end{array}$ & Unique lessons learned and best practices \\
\hline 1999-2020 & $\begin{array}{l}\text { - A regional Scientific and Technical Committee was } \\
\text { established and Regional Working Groups were set up } \\
\text { under thematic areas of ecosystem, investment, pollution, } \\
\text { biodiversity and fisheries; } \\
\text { - Regional guidelines for pollution monitoring were drafted } \\
\text { which included suggested areas to be monitored, } \\
\text { parameters, collaboration with existing national programs } \\
\text { and recommendations for future regional monitoring } \\
\text { activities; } \\
\text { - Through the series of projects, national and regional } \\
\text { commitments to international conventions and agreements } \\
\text { were encouraged (i.e., United Nations Convention on the } \\
\text { Law of the Sea (UNCLOS), the FAO Code of Conduct for } \\
\text { Responsible Fisheries, and the Global Program of Action for } \\
\text { the Protection of the Marine Environment from Land-based } \\
\text { Activities); } \\
\text { - Updated TDA (adopted in October 2020) and an updated } \\
\text { SAP covering the period of 2020-2030. } \\
\text { - To assist the operationalization of the YSLME governance } \\
\text { mechanism, the Project put into operation the Interim } \\
\text { Commission Council (ICC) supported by subsidiary bodies } \\
\text { such as Regional Working Groups, the Inter-Ministerial } \\
\text { Coordination Committees (IMCCs), National Working } \\
\text { Groups, and the Project Management Office (PMO). }\end{array}$ & $\begin{array}{l}\text { - Establishing Regional Working Groups across thematic } \\
\text { subjects provided a good mechanism for facilitating effective } \\
\text { regional cooperation at both the political and technical levels; } \\
\text { - Collaborating with other regional initiatives (PEMSEASSDS-SEA, } \\
\text { NOWPAP, NEAMPAN, and others) enhances the likelihood that } \\
\text { the results achieved will be sustained; } \\
\text { - Sustainability plans should be prepared prior to the finalization } \\
\text { of donor funded projects that outline all follow up actions to } \\
\text { ensure durability of the results achieved; } \\
\text { - Champions for sustaining the Yellow Sea Partnership } \\
\text { (individuals and organizations) should be identified to facilitate } \\
\text { and advocate for implementation of the sustainability plan; } \\
\text { - Instituting the YSLME regional governance mechanism through } \\
\text { the mandates of existing technical cooperation arrangements is } \\
\text { a practical approach that should be built upon; } \\
\text { - To help maintain consistency and coherency in addressing the } \\
\text { issues faced by the YSLME, key stakeholders from the previous } \\
\text { project phases were involved; } \\
\text { - Considering the complex project strategy and time required to } \\
\text { facilitate transboundary governance, a four year timeframe to } \\
\text { implement a project in support of the SAP is too short; } \\
\text { - To help facilitate better cross-sectoral, inter-sectoral, and } \\
\text { regional cooperation, there should be interaction across the } \\
\text { various working groups. }\end{array}$ \\
\hline
\end{tabular}


lessons learned from the case studies presented, there is a need for a road map to be included at the SAP endorsement stage which clearly outlines a mid to long term strategy for countries to maintain and own the results achieved;

- The inclusion of development financial institutions, especially regional development banks, would strengthen the implementation of the SAP. While absent from earlier TDA-SAP Process and LME Approach projects, concerted effort is being made to include activities and outputs of the SAP which align with their strategies;

- There is often a long transition period between the TDA-SAP development phase and then the actual implementation of a SAP. This creates a problem for LME management due to loss of capacity, uncertainty in the next steps, and lack of commitment;

- Harmonizing laws and policies between countries is necessary but ambitious, challenges to achieving such harmonization can create a loss of support to the SAP process;

- Poor performance and lack of commitment to the TDASAP and LME process is created if they are not embedded in the most appropriate institution(s), ultimately posing a risk to sustainability of the management of the LME.

The United Nations Development Programme (2017) review also identifies common lessons learned from the TDA-SAP Process and LME Approach that could inform and guide future initiatives, which include:

- Establishment of activity or regional centers in LME countries helps to instill a sense of ownership and commitment at a national level;

- Anchoring the TDA-SAP process in an institute which has well established regional experience and has facilitated decision making provides a solid foundation for collaboration and sustainability of the management objectives;

- The development of National Action Plans which complement the SAP implementation process has proven to be beneficial in providing additional support to the transboundary management process;

- Creating strong partnerships within the LME enables the distribution of responsibilities and sharing accountability among stakeholders;

- Governance assessments are a valuable tool to the TDA for identifying the shortcomings of existing governance arrangements;

- The "user pays" approach through licenses and fees from LME-wide processes has the potential to provide additional funding for national and transboundary institutions;

- The TDA-SAP process and LME Approach have been well documented; ensuring that lessons learned and best practices are captured for replication and guidance to future initiatives.

As described by GEF LME:LEARN (2020), effective LME governance is a complex and dynamic challenge. The following policy recommendations have been identified to strengthen transboundary LME governance: (a) important trade-offs should be evaluated when considering binding and non-binding agreements for long-term transboundary LME governance; and (b) national legislative endorsement of the SAP or a similar strategy planning document can lead to long-term success, not just within national boundaries, but also at the scale of LMEs (GEF LME:LEARN, 2020).

The GEF International Waters focal area has been recognized as an active player directly involved in strengthening regional ocean legal agreements and frameworks, with documented support to eight of the eighteen regional seas conventions and five regional fisheries commissions (Global Environment Facility Independent Evaluation Office, 2018). While concerns have been raised about the governance structures related to LME-wide management, good successes have been identified with sensible recommendations for improvement of the process.

\section{CONCLUSION}

The journey toward negotiation, ministerial endorsement and effective implementation of a LME Strategic Action Program can represent an outcome of almost two decades or more of collaborative work toward building and sustaining regional approaches to effective ocean governance. They are the product of considerable regional consultations and a well-documented GEF International Waters science to policy process (TDA-SAP Process). As reflected in the LME Approach examples shared, the process is highly adaptable to regional circumstances, especially where considerable scientific support is present and a mechanism is required to navigate the obstacles in transboundary governance to accelerate progress in sustainable management. While there are instances where it has been necessary to go beyond the traditional TDA framework and to carry out more innovative analyses at different levels, the experiences and lessons learned are of great value for replication in other regions. Establishing clear priorities for action as demonstrated by the TDA-SAP Process enables the coordination of policies, institutional reform, and national/regional investments. Notably, the development and endorsement of a SAP is a significant milestone toward achieving regional ocean governance, however; sustained efforts by all stakeholders is a necessity to ensure the sustainability of ecosystem services for livelihoods, economic and social development. It is evident that the TDA-SAP Process has improved governance in LMEs and benefited transboundary countries, but it can be made more effective by applying the common lessons learned and recommendations proposed.

\section{AUTHOR CONTRIBUTIONS}

ND wrote most of the manuscript with contributions from $\mathrm{AH}$, VM, MH, and IT. All authors contributed to the article and approved the submitted version. 


\section{ACKNOWLEDGMENTS}

The authors wish to acknowledge the citation of numerous documents and reports developed by the highlighted GEF funded and UNDP Implemented Large Marine Ecosystem projects, including Project Documents (ProDocs), Transboundary Diagnostic Analyses, Strategic Action Program, Mid-term Evaluation Reports, Terminal Evaluation Reports, Results Notes,

\section{REFERENCES}

Abe, J., Brown, B., Ajao, E. A., and Donkor, S. (2016). Local to regional polycentric levels of governance of the guinea current large marine ecosystem. Environ. Dev. 17, 287-295. doi: 10.1016/j.envdev.2015. 06.006

Abidjan Declaration (2012). Third Meeting of the Committee of West and Central African Ministers of the Guinea Current Marine Ecosystem Project / Interim Guinea Commission. Available online at: http://gclme.iwlearn.org/documentscentre/legal-documents/the-abidjandeclaration/view (accessed February 25, 2021).

Abuja Declaration (2006). Available online at: http://gclme.iwlearn.org/meetingsworkshops/meetings/abuja-declaration (accessed February 24, 2021).

Accra Declaration (1998). The Accra Declaration on the Environmentally Sustainable Development of the Large Marine Ecosystem of the Gulf of Guinea. 9-10 July 1998. Accra, Ghana. Available online at: http://gefgclme.chez.com/ english/accra.htm (accessed February 24, 2021).

Benguela Current Commission (2014). Strategic Action Programme 2015 - 2019. Available online at: https://iwlearn.net/documents/31145 (accessed November 5, 2020).

Benguela Current Convention (2013). Available online at: https://www. benguelacc.org/index.php/en/about/the-benguela-current-convention (accessed November 5, 2020).

Bensted-Smith, R., and Kirkman, H. (2010). Comparison of Approaches to Management of Large Marine Areas. Cambridge, UK: Conservation International. Washington, DC and Cambridge: Fauna \& Flora International.

Black Sea Commission (2008). State of Environment of the Black Sea (20012006/7). Edited by Temel Oguz. Publications of the Commission on the Protection of the Black Sea Against Pollution (BSC) 2008-3. Istanbul: Black Sea Commission.

Black Sea Commission (2009). Strategic Action Plan (SAP) for the Environmental Protection and Rehabilitation of the Black Sea. Istanbul: Black Sea Commission.

Black Sea Ecosystem Recovery Project [BSERP] (2005). Black Sea Ecosystem Recovery Project. UNDP/GEF: Control of eutrophication, hazardous substances and related measures for rehabilitating the Black Sea ecosystem: Tranche 2 Website. Istanbul: BSERP.

Chapman, B., and Fong, P. (2018). Mid-term Review Final Report. UNDP/GEF: Implementation of Global and Regional Oceanic Fisheries Conventions and Related Instruments in the Pacific Small Island Developing States project (PIOFMP-II). New York, NY: UNDP.

CLME (2007). Overview of the Sub-regional Preliminary Transboundary Diagnostic Analyses for the Caribbean Large Marine Ecosystem and its Adjacent Region, the North Brazil Shelf. Available online at: https://clmeplus.org/app/uploads/2020/ 04/CLME-PDF-B-2007-Preliminary-TDA-overview.pdf (accessed November 2, 2020).

CLME+ (2020a). Partnership Alliance. UNDP/GEF: CLME+: Catalysing Implementation of the Strategic Action Programme for the Sustainable Management of shared Living Marine Resources in the Caribbean and North Brazil Shelf Large Marine Ecosystems Project. Available online at: https://clmeplus.org/partnership-alliance/ (accessed November 2, 2020).

CLME+ (2020b). Regional Coordination Mechanisms. UNDP/GEF: CLME+: Catalysing Implementation of the Strategic Action Programme for the Sustainable Management of shared Living Marine Resources in the Caribbean and North Brazil Shelf Large Marine Ecosystems Project. Available online at: https://clmeplus.org/regional-coordination-mechanisms/ (accessed November $4,2020)$.
Experience Notes, and project websites. All content generated by the GEF International Waters Focal Area is archived by the GEF funded International Waters Learning Exchange and Resources Network (GEF IW:LEARN) implemented by UNDP and UNEP, and executed by IOC-UNESCO. Costs of the article processing of this publication were generously financed by the Swedish International Development Cooperation Agency.

CLME+ PROJECT (2017). Coordination Mechanism for Improved Ocean Governance between Regional Organisations in the Caribbean Formalised. UNDP/GEF: CLME+: Catalysing Implementation of the Strategic Action Programme for the Sustainable Management of shared Living Marine Resources in the Caribbean and North Brazil Shelf Large Marine Ecosystems Project. Available online at: https://www.clmeproject.org/sap-icm-formalised/\#more3931 (accessed November 2, 2020).

Convention for Cooperation in the Protection and Development of the Marine and Coastal Environment of the West and Central African Region (1981). Available online at: http://www2.ecolex.org/server2neu.php/libcat/docs/TRE/ Full/En/TRE-000547.txt (accessed February 25, 2021).

Convention on the Conservation and Management of High Migratory Fish Stocks in the Western and Central Pacific Ocean (2004). Available online at: https: //www.wcpfc.int/convention-text (accessed February 25, 2021).

Convention on the Protection of the Black Sea Against Pollution (1992). Available online at: http://www.blacksea-commission.org/Official\%20Documents/The\% 20Convention/full\%20text/ (accessed February 25, 2021).

Debels, P., Fanning, L., Mahon, R., McConney, P., Walker, L., Bahri, T., et al. (2017). The CLME+ strategic action programme: an ecosystems approach for assessing and managing the Caribbean Sea and North Brazil shelf large marine ecosystems. Environ. Dev. 22, 191-205. doi: 10.1016/j.envdev.2016. 10.004

Duda, A. (2016). Strengthening global governance of Large Marine Ecosystems by incorporating coastal management and Marine Protected Areas. Environ. Dev 17, 249-263. doi: 10.1016/j.envdev.2015.06.003

Fanning, L., Mahon, R., Baldwin, K., and Douglas, S. (2015). Transboundary Waters Assessment Programme (TWAP) Assessment of Governance Arrangements for the Ocean, Volume 1: Transboundary Large Marine Ecosystems. Paris: IOCUNESCO.

Fanning, L., Mahon, R., McConney, P., Angulo, J., Burrows, F., Chakalall, B., et al. (2007). A large marine ecosystem governance framework. Mar Policy 31, 434-443.

Fox, A., and Buijs, P. (2008). Final Evaluation RER/01/G33. UNDP/GEF Black Sea Ecosystem Recovery Project. Istanbul: United Nations Development Programme.

GEF IW:LEARN (2020). GEF Transboundary Diagnostic Analysis/Strategic Action Programme Manual. Available online at: https://iwlearn.net/documents/32989 (accessed November 6, 2020).

GEF LME:LEARN (2018). Large Marine Ecosystems Governance Toolkit. Available online at: https://iwlearn.net/manuals/governance-toolkit (accessed November $6,2020)$.

GEF LME:LEARN (2020). Transboundary LME Governance: The Importance of Political Commitment for Large Marine Ecosystem Management. Available online at: https://iwlearn.net/resolveuid/58b4f8bb-42dd-4ca69450-7546190e0f43 (accessed November 6, 2020).

Global Environment Facility Independent Evaluation Office (2018). International Waters Focal Area Study. Evaluation Report No. 114. Washington, DC: Global Environment Facility Independent Evaluation Office.

Global Environment Facility [GEF] (2020). International Waters. Available online at: https://www.thegef.org/topics/international-waters (accessed November 14, 2020).

Hamukuaya, H., Attwood, C., and Willemse, N. (2016). Transition to ecosystembased governance of the Benguela current large marine ecosystem. Environ. Dev. 17, 310-321. doi: 10.1016/j.envdev.2015.06.013

Hanchard, B. (2011). Global Environment Facility International Waters Experience Note. UNDP/GEF: Pacific Islands Oceanic Fisheries Management Project 
(OFMP). Available online at: https://iwlearn.net/documents/7088 (accessed November 11, 2020).

Hudson, A., and Glemarec, Y. (2012). Catalysing Ocean Finance, Volumes I and II. New York, NY: UNDP.

Humphrey, S., and Gordon, C. (2012). Terminal Evaluation. UNEP/GEF: Combating Living Resources Depletion and Coastal Area Degradation in the Guinea Current Large Marine Ecosystem (GCLME) Through EcosystemBased Regional Actions Project. New York, NY: United Nations Environment Programme Evaluation Office.

Kinley, D. H. (2002). Science Serving People: IAEA Technical Co-Operation for Development. Vienna: International Atomic Energy Agency.

Lenoci, J., and Shuo, L. (2020). Terminal Evaluation Report. UNDP/GEF: EAS: Implementation of the Yellow Sea LME Strategic Action Programme for Adaptive Ecosystem-Based Management Project. New York, NY: UNDP.

Mahon, R., Fanning, L., and McConney, P. (2011). CLME: Fisheries Ecosystems Governance Transboundary Diagnostic Analysis. UNDP/GEF: Caribbean Large Marine Ecosystem and Adjacent Areas (CLME) Project. New York, NY: UNDP.

Mahon, R., Fanning, L., McConney, P., and Pollnac, R. (2010). Governance characteristics of large marine ecosystems. Mar Policy 34, 919-927. doi: 10. 1016/j.marpol.2010.01.016

Merla, A. (2018). Mid-term Review. UNDP/GEF: Catalysing Implementation Of The Strategic Action Program For The Sustainable Management Of Shared Living Marine Resources In The Caribbean And North Brazil Shelf Large Marine Ecosystems (CLME+) Project. Available online at: https://clmeplus.org/app/ uploads/2020/05/CLME-MTR-FINAL-112018pdf.pdf (accessed November 2, 2020).

Odessa Ministerial Declaration on the Protection of the Black Sea (1993). Available online at: http://www.blacksea-commission.org/Official\%20Documents/ Regional\%20Commitment/ (accessed February 25, 2021).

Pacific Islands Forum Fisheries Agency [FFA] (2018). Strategic Action Programme for the Sustainable Management of Living Oceanic Resources by the Small Island Developing States of the Western and Central Pacific. Available online at: https://www.ffa.int/system/files/Oceanic\%20Fisheries\%20Management $\%$ 20in\%20the\%20Pacific\%20-\%20Strategic\%20Action\%20Programme\%2015\% 20October\%202018.pdf (accessed November 22, 2020).

Pacific Islands Forum Fisheries Agency [FFA] (2019). Tuna Fisheries Report Card 2019. Alexandria: FFA.

Rochette, J., Billé, R., Molenaar, E. J., Drankier, P., and Chabason, L. (2015). Regional oceans governance mechanisms: a review. Mar. Policy 60, 9-19. doi: 10.1016/j.marpol.2015.05.012

Sherman, K. (2005). "A modular strategy for recovery and management of biomass yields in large marine ecosystems," in Strategic Management of Marine Ecosystems, eds E. Levner, I. Linkov, and J.-M. Proth (The Netherlands: Springer), 65-80. doi: 10.1007/1-4020-3198-x_4

Sherman, K. (2019). "Large marine ecosystems," in Encyclopaedia of Ocean Sciences, 3rd Edn, eds J. K. Cochran, J. H. Bokuniewicz, and P. L. Yager (The Netherlands: Elsevier), 709-723.

South Pacific Regional Environment Programme (1997). Strategic Action Programme for International Waters of Pacific Islands. Available online at: https: //iwlearn.net/documents/6638 (accessed November 22, 2020).

Tortell, P., and Tarte, S. (2004). Terminal evaluation of the Oceanic Fisheries Management component. UNDP/GEF: Implementation of the Strategic Action Programme (SAP) of the Pacific Small Island Developing States. Available online at: https://iwlearn.net/documents/6389 (accessed November 21, 2020).

United Nations Development Programme (1992). Project Document. UNDP/GEF: Water Pollution Control and Biodiversity Conservation in the Gulf of Guinea Large Marine Ecosystem (LME). Available online at: https://iwlearn.net/ documents/3600 (accessed November 1, 2020).

United Nations Development Programme (1996). Strategic Action Plan for the Rehabilitation and Protection of the Black Sea. UNDP/GEF: Black Sea Environmental Programme (BSEP). Available online at: https://iwlearn.net/ documents/30337 (accessed November 1, 2020).

United Nations Development Programme (1997). Black Sea Environmental Programme: Final Report. UNDP/GEF: Black Sea Environmental Programme (BSEP). Available online at: https://iwlearn.net/resolveuid/ 8f1f829d1de5efd2d4b360b2791a9f8c (accessed November 1, 2020).

United Nations Development Programme (1999). Transboundary Diagnostic Analysis of the Benguela Current. UNDP/GEF: Integrated Management of the
Benguela Current Large Marine Ecosystem (BCLME) Programme. Available online at: https://iwlearn.net/documents/6685

United Nations Development Programme (2000a). Project Brief. UNDP/GEF: Implementation of the Strategic Action Program (SAP) Toward Achievement of the Integrated Management of the Benguela Current Large Marine Ecosystem (LME). New York, NY: United Nations Development Programme.

United Nations Development Programme (2000b). Yellow Sea Large Marine Ecosystem Preliminary Transboundary Diagnostic Analysis. Available online at: https://iwlearn.net/resolveuid/d066663c6e3935d55e93d15b1061e7ca (accessed November 17, 2020).

United Nations Development Programme (2001). Project Document. UNDP/GEF: Integrated Management of the Benguela Current Large Marine Ecosystem (BCLME) Programme. Available online at: https://iwlearn.net/documents/6686 (accessed November 1, 2020).

United Nations Development Programme (2002). Project Document. UNDP/GEF: Reducing Environmental Stress in the Yellow Sea Large Marine Ecosystem (YSLME). Available online at: https://iwlearn.net/documents/6442 (accessed November 5, 2020).

United Nations Development Programme (2004a). Control of eutrophication, hazardous substances and related measures for rehabilitating the Black Sea ecosystem: Tranche 2. Project Document. New York, NY: United Nations Development Programme.

United Nations Development Programme (2004b). Project Document. UNDP/GEF: Pacific Islands Oceanic Fisheries Management Project. Available online at: https://iwlearn.net/resolveuid/4a53b3920428b865e92f8d60731194e4 (accessed November 22, 2020).

United Nations Development Programme (2005). Mid-Term Evaluation Report. UNDP/GEF: Integrated Management of the Benguela Current Large Marine Ecosystem (BCLME) Programme. Available online at: https://archive.iwlearn. net/bclme.org/ (accessed November 5, 2020).

United Nations Development Programme (2006). Guinea Current Large Marine Ecosystem Transboundary Diagnostic Analysis. Available online at: https:// iwlearn.net/documents/31166 (accessed November 7, 2020).

United Nations Development Programme (2007a). Black Sea Transboundary Diagnostic Analysis. Available online at: https://iwlearn.net/resolveuid/ 027884cd-d97e-4ec5-ac6b-60f4db3f277f (accessed November 3, 2020).

United Nations Development Programme (2007b). International WatersDelivering Results. Available online at: https://www.undp.org/content/dam/ undp/library/Environment\%20and\%20Energy/Water\%20and\%20Ocean $\%$ 20Governance/UNDP-GEF\%20IW\%20Report\%202007.pdf (accessed November 7, 2020).

United Nations Development Programme (2007c). Guinea Current Large Marine Ecosystem Strategic Action Programme. Available online at: https://iwlearn.net/ documents/4689 (accessed November 2, 2020).

United Nations Development Programme (2007d). Mid-Term Evaluation. UNDP/GEF: Reducing Environmental Stress in the Yellow Sea Large Marine Ecosystem (YSLME). Available online at: https://iwlearn.net/documents/ 5267 (accessed November 1, 2020).

United Nations Development Programme (2008). Final Evaluation Report. UNDP/GEF: Integrated Management of the Benguela Current Large Marine Ecosystem (BCLME) Programme. Available online at: https://iwlearn.net/ documents $/ 3545$

United Nations Development Programme (2009a). Project Document. UNDP/GEF: Sustainable Management of the Shared Living Marine Resources of the Caribbean Large Marine Ecosystem (CLME) and Adjacent Regions. Available online at: https://iwlearn.net/documents/3770 (accessed November 7, 2020).

United Nations Development Programme (2009b). Strategic Action Programme for the Yellow Sea Large Marine Ecosystem. UNDP/GEF: Reducing Environmental Stress in the Yellow Sea Large Marine Ecosystem Project. Available online at: https://iwlearn.net/documents/26492 (accessed November 10, 2020).

United Nations Development Programme (2011). Terminal Evaluation. UNDP/GEF: Pacific Islands Oceanic Fisheries Management Project (OFMP). Available online at: https://iwlearn.net/documents/3015 (accessed November 11, 2020).

United Nations Development Programme (2012a). International WatersDelivering Results. Available online at: https://www.undp.org/content/undp/ 
en/home/librarypage/environment-energy/water_governance/internationalwaters--delivering-results.html (accessed November 17, 2020).

United Nations Development Programme (2012b). Catalysing Ocean Finance Volume II Methodologies and Case Studies. Available online at: https://iwlearn. net/documents/3123 (accessed November 6, 2020).

United Nations Development Programme (2013a). Synthesis Report. Towards Ecosystem-based Management of the Guinea Current Large Marine Ecosystem. New York, NY: United Nations Development Programme.

United Nations Development Programme (2013b). The Strategic Action Programme for the sustainable management of the shared living marine resources of the Caribbean and North Brazil shelf large marine ecosystems (CLME+SAP). UNDP/GEF: Caribbean Large Marine Ecosystem and Adjacent Areas (CLME) Project. New York, NY: United Nations Development Programme.

United Nations Development Programme (2014a). Project Document. UNDP/GEF: CLME+: Catalysing Implementation of the Strategic Action Programme for the Sustainable Management of shared Living Marine Resources in the Caribbean and North Brazil Shelf Large Marine Ecosystems Project. New York, NY: United Nations Development Programme.

United Nations Development Programme (2014b). Project Document. UNDP/GEF: Implementation of Global and Regional Oceanic Fisheries Conventions and Related Instruments in the Pacific Small Island Developing States. New York, NY: United Nations Development Programme.

United Nations Development Programme (2014c). Project Document. UNDP/GEF: Implementing the Strategic Action Programme for the Yellow Sea Large Marine Ecosystem: Restoring Ecosystem Goods and Services and Consolidation of a Longterm Regional Environmental Governance Framework. New York, NY: United Nations Development Programme.

United Nations Development Programme (2016). International Waters-Delivering Results. New York, NY: United Nations Development Programme.

United Nations Development Programme (2017). Large Marine Ecosystems and Sustainable Development: A review of Strategic Management Processes and Goals. New York, NY: United Nations Development Programme.
United Nations Development Programme (2020). Transboundary Diagnostic Analysis for the Yellow Sea Large Marine Ecosystem (2020). UNDP/GEF: Implementation of the Yellow Sea LME Strategic Action Programme for Adaptive Ecosystem-Based Management. New York, NY: United Nations Development Programme.

United Nations Environment Programme (2017). Project Identification Form. UNEP/GEF: Strengthening of the enabling environment, ecosystem-based management and governance to support implementation of the Strategic Action Programme of the Guinea Current Large Marine Ecosystem Project. Nairobi: United Nations Environment Programme.

Van Lavieren, H., and Hanneke, L. (2015). From Coast To Coast: Celebrating 20 Years of Transboundary Management of Our Shared Oceans. Washington: The Global Environment Facility.

Whalley, P. (2011). CLME: Regional Transboundary Diagnostic Analysis. UNDP/GEF: Caribbean Large Marine Ecosystem and Adjacent Areas (CLME) Project. New York, NY: United Nations Development Programme.

Yellow Sea Large Marine Ecosystem (2020). YSLME Commission. UNDP/GEF: Implementing the Strategic Action Programme for the Yellow Sea Large Marine Ecosystem. New York, NY: Yellow Sea Large Marine Ecosystem.

Conflict of Interest: The authors declare that the research was conducted in the absence of any commercial or financial relationships that could be construed as a potential conflict of interest.

Copyright $\odot 2021$ Degger, Hudson, Mamaev, Hamid and Trumbic. This is an openaccess article distributed under the terms of the Creative Commons Attribution License (CC BY). The use, distribution or reproduction in other forums is permitted, provided the original author(s) and the copyright owner(s) are credited and that the original publication in this journal is cited, in accordance with accepted academic practice. No use, distribution or reproduction is permitted which does not comply with these terms. 